\title{
Ethnic conflict and Eurasian security
}

\author{
Stuart Kaufman
}

What role does ethnic conflict play in Eurasian security affairs? Just breaking this question down into its component parts uncovers a vast array of apparent influences. Ethnic conflict is, first of all, clearly a cause of internal conflict and insecurity, as demonstrated by the problems in Bosnia, Kosovo, Macedonia, Cyprus, Georgia, Chechnya and Mountainous Karabagh. Furthermore, it is a key cause of international security problems, as the above list of ethnic civil wars illustrates: most of these conflicts have attracted involvement by neighbouring countries, and some have all along been as much interstate as intra-state disputes. But ethnic conflicts do not only cause international insecurity; they may also be in part a result of security competition. Bosnia's conflict, for example, was driven in large part by rivalry between Serbia and Croatia; Macedonia's violence is largely a spillover from the Kosovo conflict; and separatist conflicts continue in Azerbaijan and Georgia due in large part to Russian support for the separatists.

All of these dynamics combine with other sorts of security competition in the region to create significant security dilemma problems. Russian statesmen feel, for example, that a more or less exclusive Russian sphere of influence in the Caspian region, and especially in the Caucasus, is essential for Russian security. Indeed, they blame their Chechnya problems in large part on the absence of such predominance. Obviously, however, these hegemonic ambitions clash with the basic goals of security, sovereignty and territorial integrity of the states in the region, especially Georgia and Azerbaijan. The existence of those clashes, in turn, threatens the American and Turkish security interests of stabilising the Caucasus so they can obtain access to the energy resources of the region.

The key to sorting out these complex influences lies in rethinking the source and nature of the security dilemma both internally and internationally. In international relations theory, the debate has been primarily 
between neo-realists, who argue that international anarchy ipso facto causes security dilemmas, and neo-liberal institutionalists, who argue that institutions can help head off security dilemmas. Both sides have also tried to apply their ideas to internal ethnic conflicts. Self-identified constructivists cover this whole range of possible arguments, and much more territory besides.

Many of these arguments can be reconciled using a particular constructivist approach. As Randall Schweller has argued, the existence of an international security dilemma requires the existence of revisionist states requires, that is, that states construct their security interests to require expansion. ${ }^{1}$ When states construct their security needs in mutually accommodating ways, as within the western security community, there is no security dilemma. ${ }^{2}$ The same insight applies to ethnic conflict: the critical cause of ethnic conflict is the construction of ethnic groups' vital interests in conflicting ways, typically in terms of mutually exclusive claims to the same territory. Where states or groups construct their interests in ways that are mutually reconcilable, neo-liberal institutionalist prescriptions for conflict management and conflict resolution can work. Where security interests are constructed in mutually exclusive ways, neo-realist objections to neo-liberal arguments apply.

In the hot spots of Eurasia, security dilemmas continue to exist within and between states because states and groups define their security in mutually exclusive ways. In ethnic conflicts such as those in the Balkans, institutional arrangements to manage conflict will remain fragile as long as and to the degree that ethnic attitudes and goals remain mutually hostile. Furthermore, even the fragile effectiveness of existing institutions will continue only as long as the distribution of power discourages the dissatisfied from trying again which means, in large measure, only as long as the US remains engaged. In the Caucasus, the parties have constructed their interests to rule out compromise: those elites who might be inclined to seek a compromise settlement are prohibited by public opinion from reaching any agreements. There, renewed war is prevented only by the continuing military superiority of the victors of the last rounds of fighting. Effective institutional arrangements for conflict management do not exist and cannot be built in current circumstances. In both places, 'peace-building' efforts aimed at shifting public attitudes are necessary, and are the only available policy tools that can contribute to stability in the long run. However, peace-building efforts would face tough sledding in any case, and the Bush administration's 'realist' foreign policy has not contributed to the mitigation of the regional security dilemmas, especially in the Caucasus and the Balkan states.

\section{Understanding Eurasia's ethnic wars}

Scholars, practitioners and journalists have developed a number of different ideas about how to explain the ethnic violence in Eurasia. The most 
prominent of these include the 'ancient hatreds' argument most popular among journalists, ${ }^{3}$ the 'elite manipulation' story favoured by most rational choice theorists, ${ }^{4}$ the security dilemma argument focused on internal instability, ${ }^{5}$ and arguments focused on foreign influences - 'bad neighbours' and 'bad neighbourhoods'. ${ }^{6}$ These diagnoses can lead to starkly different policy prescriptions. Misha Glenny, whose work tilts toward the ancient hatreds school, argues that the violence can stop only if outside powers intervene by force, ${ }^{7}$ while Robert Kaplan, who represents the same school of thought, argues that such intervention can stop the violence only temporarily. Rational choice theorists focused on elite behavior and institutional structure tend to argue that the solutions are found in appropriate institutional arrangements supplemented by international action as guarantors. ${ }^{8}$ Security dilemma theorists argue that power-sharing institutions are hopelessly ineffective, so only partition can resolve or at least reduce violent conflicts. ${ }^{9}$ And those who study international factors focus on the importance of deterring 'bad neighbours' from destructive interventions. ${ }^{10}$

All of these arguments, however, miss the central source of the problem: where do ethnic hatreds - which are not, in fact, 'ancient' - come from? Why do mass publics follow manipulative elites into war? Why do intermingled ethnic groups sometimes fight with each other when government is weak, but more typically avoid such fighting? ${ }^{11}$

The answers are found, in large part, in ethnic or nationalist mythologies and the manipulation of emotional symbols identified in those myths. ${ }^{12}$ Ethnic groups are, as Benedict Anderson has said of nations, 'imagined communities'; they exist only because of a body of ethnic myths that define them. These myths, as Anthony Smith argues, typically identify who is in the group, how members are distinguished from non-members, a common set of cultural beliefs, a common name and history, what it means to be a group member, and, often, who the group's enemies are. ${ }^{13}$ These divisions and identifications are always to some extent arbitrary. Serbs and Croats, for example, share a language but count each other as enemies on religious and historical grounds. Abkhazians, in contrast, though divided religiously, make common cause against the linguistically different Georgians, and ally with Russia to do so even though Russia was the perpetrator of Abkhazia's great historical tragedy, an ethnic cleansing campaign in the late nineteenth century.

What matters is the degree to which ethnic or nationalist myths justify hostility against other groups. Nationalist Serbs, for example, identify Croats with the World War II-era Ustashe fascists, and they identify Muslim Bosnians and Albanians with the hated Ottoman Turks - so they fought these groups in Bosnia and Kosovo. On the other hand, Serbs and Macedonians, though not particularly friendly towards each other, have tried to cooperate against the Muslim Albanians, who are seen by both groups as the national enemy. 
These myths, and the hostility or hatred they generate, are not, however, ancient; they are modern. While Serbian mythology dates Serbs' hostility to Muslims to the 1389 Battle of Kosovo Field, for example, there was little popular ethnic tension before the myths of Kosovo were resurrected in the nineteenth century by Serbian propagandists, many working for the newly independent Serbian state. ${ }^{14}$ And Serbs' hostility to Croats is based primarily on the symbolism of Croats as Ustashe fascists, which dates only to World War II and to postwar mythologising. Similarly, while Armenian mythology traces the roots of the nation to ancient times, and singles out Turks as historical enemies, Armenian national consciousness - and their national conflict with the Turks - dates only to the 1890-1915 period, when the Armenian national 'awakening' led to several rounds of ethnic violence between Armenians and Turks (including Azerbaijani Turks), culminating in the 1915 genocide. $^{15}$

Such hostile myths are, however, more common than ethnic violence. If severe violence is to occur, hostile ethnic myths must be activated by some threat that leads members of at least one group to fear ethnic extinction. Thus the problem that set Yugoslavia ablaze was that Milosevic's grab for Serb domination provoked a countervailing Croatian nationalism, which in turn led the Serbs of Croatia to fear ethnic cleansing or genocide by a neofascist Croatian regime. The Armenians of Mountainous Karabagh in Azerbaijan, similarly, feared a creeping ethnic cleansing or 'white genocide' as a result of continuing, long-term Azerbaijani discrimination, while their response - a secessionist movement - threatened the dismemberment of Azerbaijan.

It is only in the context of such myths and fears that ethnic elites can mobilise popular opinion behind ethnic extremism, once they have the opportunity to do so. In some cases, most famously Milosevic's, incumbent leaders can manipulate myths like the Battle of Kosovo and symbols like Prince Lazar, doomed hero of that battle, by using their control over the media to dominate public debate and thereby promote an extreme nationalist program. The extremist program is key: ethnic war occurs only if the sides define their groups' security in mutually exclusive ways. Croats, for example, felt unsafe in a Yugoslavia dominated by Milosevic, so they decided to secede, while the Serbs of Croatia felt unsafe under an independent nationalist Croatian government, so they tried to split from Croatia. These conflicting security demands impelled both sides to fight.

Ethnic mobilisation does not, however, have to come as the result of elite manipulation. In some cases, popular myths and fears are strong enough for a street-corner agitator who harps on nationalist themes to become a nationalist hero, at least briefly. In Georgia, for example, the Communist Party leadership under First Secretary Jumber Patiashvili tried hard to suppress rising nationalist sentiment in the late 1980s, but was unable to arrest the rise of dissident journalist Zviad Gamsakhurdia to power, or to 
prevent the eruption of ethnic violence between Georgians and the minority South Ossetians. Georgian mythology painted the South Ossetians as 'recent' (seventeenth-century) migrants to Georgia with no right to their autonomous region; the South Ossetians, feeling threatened, countermobilised and the result, eventually, was war. ${ }^{16}$

Finally, foreign actors may play a critical role in turning ethnic conflict into war regardless of whether mobilisation is mass-led or elite-led. In the absence of external help, rebels or secessionists typically have little hope against the armed might of the state. With it, however, they are more likely to try to fight and more likely to win. Victims of 'bad neighbours' include Moldova and Georgia, whose secessionist groups would have lacked the ability to fight without Russian help, and Mountainous Karabagh, where the Armenians' victory over Azerbaijan was equally the result of Russian assistance. And the fights in Croatia and Bosnia occurred mostly because of the influence of Belgrade on their Serbian minorities. Macedonia's current troubles are more a case of a 'bad neighbourhood': no government in the region is trying to destabilise Macedonia, but the conflict there is none the less the result of spillover from Kosovo next door.

In sum, all four of the rival theories of ethnic violence offer insights, but none of them accounts for the whole picture. Journalists are right that violent ethnic conflicts are driven by popular hostility and hatred, but those attitudes are modern, not 'ancient'. Rational choice theorists are right that mass publics are often manipulated by ethnic elites, but they overlook the degree to which pre-existing myths and attitudes are needed to make such manipulation possible, and they ignore the importance of emotional symbolism in enabling leaders to manipulate their followers. Security dilemma theorists are right that ethnic violence escalates because of a security dilemma, but most underestimate the degree to which the insecurity is driven by simple hostile intent - the predatory goal of domination over the other group - rather than uncertainty. ${ }^{17}$ Finally, international relations theorists are right that bad neighbours and bad neighbourhoods can have a critical influence, but they do not claim that such influences matter in the absence of the right (or wrong) internal conditions.

Furthermore, in evaluating the effects of foreign intervention in ethnic conflicts, it is important to take into account the various and powerful motives outsiders may have for such action. Ethnic chauvinism was Milosevic's ruling strategy, so he would have been pushed to intervene in Croatia and Bosnia even if he had not wanted to do so. The intervention of Russia's Fourteenth Army in Moldova's ethnic conflict in 1991-92, in contrast, was driven not so much by Moscow as by its officers who wanted to protect their own families resident in the region. ${ }^{18}$ Russia continues to support the Abkhazian separatists against Georgia largely because they consider increased influence in Georgia essential for Russian security including in Russia's fight against Chechnya, which borders on Georgia. The 
NATO interventions in Bosnia in 1995 and Kosovo in 1999 expressed the Euro-American security policy of rebuilding NATO as the premier security organisation in Europe. Continued Russian intervention in the Caucasus can, in this light, be understood as a Russian effort, driven by the security dilemma, to prevent such NATO hegemony on its southern border. Encouraging constructive international intervention and heading off the destructive kind is, in this light, harder than it looks.

\section{The dilemmas of policy intervention}

Because all of these theorists are in part right, their prescriptions for conflict resolution all have merit. Rational choice theorists are right that designing workable institutions is critical if ethnically divided states are to be rebuilt, and that external intervention can play a critical role in setting up those institutions. But ancient hatreds theorists, and security dilemma theorists such as Chaim Kaufmann, are also right that neither intervention nor new institutions can change ethnic hatreds, especially after they have been renewed and entrenched by a recent round of violence. Furthermore, there are many different sorts of foreign intervention: helping one side win the fight, for example, may lead to a quick ceasefire but also cause a long-lasting political stalemate. Sometimes military intervention seems necessary to establish a secure environment; in other cases, mediation and other peaceful interventions suffice. In some cases, the key is to deter destructive external intervention. What mix of approaches is right, and how can the sides get past the hurdle of lasting hostility?

Thinking about ethnic conflicts in terms of a symbolic politics trap helps to fill in one of the key missing pieces. Interethnic stalemates stay in place not only because of the dynamics between the two groups, but because of the dynamics within them. Once extremist leaders have used extremist ethnic symbols to gain and hold power, they often become captive to those symbols. Thus even if leaders recognise that continued ethnic confrontation may no longer be in their group's interest, they may be unable to agree to a peace settlement because of the danger of being outflanked by even more extreme opposition figures who can use those same symbols against them.

Escape from the symbolic politics trap requires yet another set of tools for outside intervention. If the problem is hostile attitudes and social dynamics that make it hard to change them, the solution has to be policies aimed at changing those attitudes and social dynamics. This is the realm of 'peacebuilding' and 'conflict transformation' - efforts at encouraging non-hostile interethnic attitudes and cooperative relationships across communal lines. ${ }^{19}$ Most typically, peace building programmes focus on dialogue between members of different ethnic groups aimed at undercutting their 'enemy image' of each other, helping participants find enough mutual empathy so that they find compromise not only thinkable but preferable to continued conflict. While such efforts work at the individual level, however, 
their effects are usually limited owing to the re-entry problem: when participants return home, they find their friends and associates unsympathetic to their new moderation, so they feel obliged to keep their views quiet. ${ }^{20}$ This points towards the need for more ambitious targets - changes in government rhetoric, media coverage and school curricula aimed at creating an atmosphere that encourages moderate attitudes, plus well-crafted efforts at promoting economic reintegration to create tangible incentives for a compromise peace.

\section{Eurasia's ethnic conflicts}

To consider further all of these problems, I turn now to several of the more prominent ethnic conflicts in Eurasia. I start with the internal dynamics of the conflicts themselves, exploring the ethnic myths and symbols at the root of the groups' conflicting identities. I then show how in each case the participants are caught in a symbolic politics trap, and are therefore locked into intractable security dilemmas resulting from the sides' - or at least their leaders' - irreconcilable, indeed predatory, goals. I then discuss the international dimensions of each conflict - the spurs and reins on international intervention, and the resulting dynamics of those interventions.

\section{Bosnia}

The war in Bosnia-Herzegovina was the largest and most destructive of Europe's ethnic wars in the 1990s, leaving over two hundred thousand dead and over two million refugees and displaced persons after a four-year war of a viciousness unseen in Europe since World War II. Since the outbreak of the conflict is typically blamed on Serbian leader Slobodan Milosevic and his allies in Bosnia, Radovan Karadzic and Ratko Mladic, it is important to point out that in Bosnia, too, hostile ethnic myths and emotive symbols provided the tinder which the sparks of Milosevic's propaganda set alight. Milosevic, Karadzic and company are indeed the main reasons for the war, but their efforts could not have succeeded in the absence of a climate receptive to their appeals.

Among the Serbs, the critical myths stemmed from the traditions about the Kosovo battle against the Turks, and from the experience (and myths) of World War II. Kosovo is the founding myth of the Serbian nation, the lost 1389 battle against the Turks that led to five centuries of Ottoman Turkish domination but, in the mythology, led also to a religious sanctification of the Serbian nation as Christian heroes of Europe and martyrs to the terrible Turk. ${ }^{21}$ The Serbian habit of referring to all Muslims as 'Turks' allows Serbs to feel about the Bosnian Muslims as they do about real Turks, in spite of the fact that Serbs and Bosnian Muslims had far more in common with each other than either did with Turks. At the same time, the mythologised memory of the horrendous fight against the Nazis and the Croatian Ustashe 
fascists inclined Bosnian Serbs to see Bosnian Croats (not entirely inaccurately) as the direct inheritors of the Ustashe. ${ }^{22}$ Serbian propaganda added to this noxious mix an additional element, labelling the Bosnian Muslims as 'Islamic fundamentalists', raising fears for the survival of the Serbian community in Bosnia.

Croatian mythology paints the Croats as a single tribe, distinguished by their Catholicism and location as the 'outer wall' of Christian Europe's defence against the early modern Ottomans. It also emphasises over a millennium of Croatian 'statehood', and as a result is ambivalent about the Ustashe interlude: as Franjo Tudjman put it, the Ustashe regime was simultaneously 'a Fascist crime' and an authentic expression of Croatian nationalist aspirations. ${ }^{23}$ The Croats of western Herzegovina, long associated with Croat extremism, were among the most avid followers of Tudjman's efforts to revive Croatian nationalism in the early 1990s and strong supporters of the dream of extending the revived Croatian statehood to their territory (dismembering Bosnia in the process).

The identity of Bosnian Muslims is more problematic. While there was, in fact, a medieval Bosnian kingdom - Bosnian King Tvrtko was a key ally of Prince Lazar and the Serbs at the Battle of Kosovo Field - no specifically Bosnian identity emerged from medieval times. Only in Tito's time did the Muslims of Bosnia make clear that they wanted recognition of their distinct identity. Since Serbs and Croats objected to construction of a 'Bosnian' identity that would include Bosnian Serbs and Croats, the 'Muslim' category was created in the Yugoslav census, and thence in Yugoslav political life. To the extent that the Bosnian Muslim identity had a political meaning, it was the vision of Alija Izetbegovic, the first president of independent Bosnia, who argued for a peaceful melding of secular western civilisation with Islamic spiritual values. ${ }^{24}$ Mostly, however, the Muslim identity was a refuge for those trapped between the unacceptable Serb and Croat visions for the republic's future.

The main cause of Bosnia's war was less these identities, however, than the policy of the Serbian leadership. Slobodan Milosevic, the president of Serbia, created the apparatus of Bosnia's Serbian Democratic Party (SDS), led by Radovan Karadzic, and the Bosnian Serb army, led by Ratko Mladic. Using the Serbian myths and manufactured fears as justification, these leaders, with assistance from Serbia, formulated a policy of remaking most of Bosnia into an ethnically 'clean' Serbian state, leaving over a small CroatMuslim rump. To implement this policy, the Bosnian Serbs launched their campaign of mass murder and ethnic cleansing, highlighted by the concentration camps at Omarska and elsewhere and the brutal siege of Sarajevo. Hardline Croats in Franjo Tudjman's HDZ simultaneously tried to carve out an ethnically Croat entity in western Herzegovina. The fighting continued until the Croatian counter-offensive of 1995, in alliance with the Bosnian Muslims and backed by NATO air strikes, presented the Serbs with the threat 
of military defeat, leading Milosevic to coerce his erstwhile Serbian allies into signing the Dayton peace accords that ended the fighting.

Those agreements established a rickety network of institutions that tried simultaneously to establish an effective central government for Bosnia and disperse virtually all effective power to two, and in practice three, ethnically based units: the Republika Srpska, the Muslim-Croat Federation, and the de facto Croat entity within the federation. On the one hand, the plan for peace centred on establishing a de facto partition: creating the ethnic entities, allowing the continued existence of separate armies and ethnically dominated local police forces, and establishing an arms-control regime. These provisions were all concessions to the predatory goals of the Serbs and Croats. On the other hand, the plan for reintegration aimed at undermining that partition in the long run: establishing a central Bosnian government, allowing for repatriation of refugees, and empowering NATO's Implementation Force (IFOR) to enforce the agreement and arrest the war criminals who were continuing to block reconciliation efforts. ${ }^{25}$ These requirements were, of course, at the demand of the Bosnian government whose goals the Serbs and Croats see as predatory.

In practice, the Dayton provisions that promote disintegration have proved stronger than those that promote reintegration, primarily because of the disinclination of IFOR (and its successor, NATO's Stabilisation Force (SFOR)) to coerce the Bosnian Serbs and Croats - whose leaders were still intent on carving up Bosnia - into implementing the provisions for reintegration. Thus IFOR refused to arrest war criminals, leaving Radovan Karadzic in power until 1996, and then accepting as his successor the initially equally hardline Biljana Plavsic. These criminal leaders, in turn, fought every effort at reintegrating Bosnia, repeatedly blocking efforts to repatriate Muslim refugees to Republika Srpska, and refusing even to accept a common licence- plate design for cars. The high representative established under the Dayton accords finally imposed the licence-plate design, but war criminals remain in control of local police and governments in Republika Srpska, have blocked most refugee repatriation, have prevented the establishment of a single Bosnian economic space, and have undermined economic reconstruction by maintaining a corrupt system of payoffs linked to organised crime networks. ${ }^{26}$ The Bosnian state remains a polite fiction, in spite of the fall of its most important external enemy, President Slobodan Milosevic of Yugoslavia.

Bosnia remains so in part because of hostile nationalist myths and attitudes, which were magnified by the horrors of the war. Serbs, Croats and Muslims all tend to deny or downplay the atrocities and murders committed by their own side, while exaggerating those committed by the others. But these attitudes are reinforced by incumbent local and entity leaders (and the media they control), all too often war leaders and war criminals with every incentive to obscure their own culpability. The November 2000 elections 
placed moderates in power in the central Bosnian government, but put the hardline SDS back in power in Republika Srpska. Not only was the SDS dominated by indicted or indictable war criminals - from wartime leader Radovan Karadzic behind the scenes to a legion of thugs in positions of local power ${ }^{27}$ - but it also ran a thoroughly corrupt economic system in which bribery, smuggling and other sorts of organised crime flourished while reconstruction and other normal economic activity was choked off. These hardliners returned to power by exploiting the symbolic politics trap, blaming other ethnic groups and the international community for the economic misery their gangsterism causes. In this context, peace-building cannot by itself promote reconciliation: while some peace building efforts have made progress in neighbouring Croatia and even in Bosnia itself, ${ }^{28}$ the general assessment of most foreign organisations in Bosnia is that the Serbs are simply not prepared to cooperate, due to hostile attitudes reinforced by hardline government officials. The symbolic politics trap in Bosnia thus remains elite-led.

\section{Macedonia}

Macedonia has, so far, managed to avoid the outbreak of all-out war between the Slavic Macedonian majority and the Albanian minority, which comprises at least a quarter of the population. The flare-up of fighting in the spring and summer of 2001 did, however, threaten to escalate into such a war, and full implementation of the fragile peace deal reached between the conflicting factions at Lake Ohrid in August of that year remains uncertain. Speaking mutually unintelligible languages, adhering to different religious faiths, and leading radically different styles of life (at least in rural areas), Macedonians and Albanians are distinctly hostile to each other, so their ability to head off full-scale war is all the more notable.

Macedonian nationalism is a new phenomenon. In the early twentieth century, there was no separate Slavic Macedonian identity; Macedonian villagers defined their identity as either 'Bulgarian', 'Serbian' or even 'Greek' depending on the affiliation of the village priest. ${ }^{29}$ The separate Macedonian nationalist mythology and national identity are essentially a post-World War II phenomenon, a product of Tito's postwar nationality policy. According to the Macedonian mythology, modern Macedonians are the descendants of the subjects of Alexander the Great. Macedonian cultural identity stems from the ninth-century Saints Cyril and Methodius, who converted the Slavs to Christianity and invented the first alphabet for a Slavic language. Macedonians trace the roots of their nationalist movement to the turn-of-the-century Internal Macedonian Revolutionary Organisation (IMRO) - actually a pro-Bulgarian group - and celebrate the anniversary of the Ilinden uprising against the Ottoman Turks in 1903 as a national holiday. Unlike the Serbs, however, the Macedonians do not typically associate Albanians with the Ottoman Turks of history. There are 
Macedonian fears of group extinction, but these fears have focused historically on the irredentist threat from Macedonia's neighbours - the 'four wolves' of Serbia, Bulgaria, Greece and Albania - as much as on the internal threat from Macedonia's Albanians. ${ }^{30}$

Albanians, for their part, claim (with more plausibility than the Macedonians) descent from another ancient group in the region, the Illyrians, and on this basis claim western Macedonia as historically theirs. According to their mythology, they have never accepted foreign rule: their national hero, Skanderbeg, led the Albanians' fight against the Ottomans in the fifteenth century; their nineteenth-century national 'awakening' was directed as much against the Turks as against their Slavic neighbours. These ideas incline them to reject Macedonian authority as well. Furthermore, the savagery of the Balkan Wars beginning in 1912 occurred largely in Macedonia, so a twentieth-century precedent of extreme mutual violence is also present.

When Macedonia achieved independence in 1991, therefore, hostile myths, group fears and political opportunity were all present, and expressions of mass hostility were common. How, then, did it avoid large-scale violence for a decade; and how did it manage to reach a compromise agreement on its ethnic conflict when fighting did break out in 2001? First, Macedonians' fear of group extinction was assuaged because they had predominant political power, while Albanian fears focused on prosaic mistreatment rather than existential concerns. Second, and most importantly, politicians on both sides - presumably deterred by the example of their northern neighbours - wanted to avoid violence, and were willing to make efforts to prevent it. Macedonian leaders always included Albanian ministers in their governments, and Albanian politicians refrained from pushing their brinkmanship tactics to the point of violence. Given this modicum of goodwill, the two sides managed to crawl slowly towards resolution of substantive issues, such as Macedonian government tolerance of the Albanian-language university in Tetovo. The United Nations provided a small peacekeeping force that helped reassure both sides of international concern.

When violence did finally erupt in 2001, it was the result of spillover from Kosovo, an uprising created by a few Albanian Macedonian extremists who had experience fighting in Kosovo. These cadres created their 'National Liberation Army' (NLA) based on the infrastructure and resources of the Kosovo Liberation Army, and with some uncertain degree of connection to the entrenched smuggling rings operating across borders in the region. The Macedonian government's reaction to the outbreak of violence was schizophrenic. On the one hand, hardliners led by Prime Minister Ljubcho Georgievski spoke of a military solution to the problem, and even the moderate President Boris Trajkovski branded the NLA as 'terrorists' (which they were not, in the sense that their usual targets of attack were Macedonian 
military and police rather than civilians). On the other hand, Trajkovski also launched talks with Albanian political parties to address many of the Albanians' longstanding concerns: increasing jobs in government administration, expanding local self-government, and extending the use of the Albanian language in government and education. The NLA, for its part, staked out a strikingly moderate political platform largely corresponding to the demands made by the Albanian political parties, but complemented by the demand for changes in discriminatory language in the Macedonian constitution.

Prodded by US and EU mediators, representatives of Macedonia's main political parties (with the legal Albanian parties acting on behalf of the NLA) signed a peace agreement in August 2001, despite rising violence promoted by extremists on both sides. The agreement was a fair-minded compromise: for example, Macedonian was to remain the official language for the government's foreign relations, but any other language spoken by 20 per cent of the population of a locality was to be a 'service language' for that locality; higher education in Albanian was also to be provided. On the political level, the two sides agreed on a power-sharing deal, effectively requiring majority Albanian support in Parliament for legislation affecting the interests of Albanians. NATO peacekeepers were introduced to collect the NLA's armaments, and implementation of the deal was to be roughly synchronised with the arms-collection process, though in practice the constitutional amendments' ratification was delayed for two months by hardline Macedonian leaders. In implementing the deal, the most controversial issue turned out to be a provision for an amnesty for NLA fighters who had not committed war crimes: Macedonian hardliners did not want to let these 'terrorists' off the hook.

Neither Macedonia's approach to war nor its subsequent move towards peaceful conflict management was surprising. The preconditions for war were present, but Macedonia is blessed in that even its extremists are relatively moderate. War erupts when both sides pursue predatory goals, sticking to mutually irreconcilable positions; the NLA instead chose a moderate political programme, and agreed to disband when its demands were largely met. On the Macedonian side, some leaders did apparently want war in pursuit of ethnic domination, but President Trajkovski, the leader of the ruling nationalist VMRO-DPME party, was not among them. Thus while a security dilemma exists - Macedonians fear Albanian separatism and lawlessness, while Albanians fear repression by violent Macedonian police and paramilitaries - it remains manageable because the sides are not pursuing predatory goals. At the same time, none of the regional or great powers had an interest in fostering violence. ${ }^{31}$ In these circumstances, the sorts of leverage available to the international community - diplomatic pressure, offers of a donor conference to implement a peace deal, pressure on foreign arms suppliers - were enough to tip the balance towards peace. 
None of this means the conflict is over; implementation of the Lake Ohrid agreement will remain problematic as Macedonian hardliners try to manipulate emotional symbolism to block Albanian gains. In the medium term, continuing strong ethnic Macedonian hostility towards Albanians, a strong chauvinist presence in the Macedonian-language media, and the persistence of the nationalist VMRO government mean that Macedonia will remain for some time on the brink of war. If war comes, however, it will be elite-led: Albanians supported the (now defunct) NLA's goals but not its violent methods, while the VMRO government came to power by downplaying its nationalist programme and forming a coalition with an Albanian faction. On both sides, mass opinion is volatile but does not want ethnic confrontation.

\section{Mountainous Karabagh}

The first ethnic conflict to explode into war in this region was the conflict between Armenians and Azerbaijanis over Mountainous Karabagh. At the time the conflict started in late 1987, there were some 475,000 Armenians in Azerbaijan, a quarter of them in the Mountainous Karabagh Autonomous Region, as well as over 100,000 Azerbaijanis in Armenia. Ethnic tensions were longstanding, in large part reflecting deeply hostile ethnic mythologies.

Armenian mythology painted the Armenian people as ancient inhabitants of the region stretching from Karabagh to eastern Turkey, inheritors of a political tradition dating back over 2,000 years, and the first nation to convert to Christianity (in $\mathrm{AD}$ 301). The mythology also characterised Armenia as a martyr nation, repeatedly victimised over the centuries by Persian and Turkish adversaries. The defining experience for the nation is, in this narrative, the 1915 Genocide, in which virtually the entire Armenian population of eastern Anatolia, over a million people, was forcibly expelled in circumstances designed to ensure the deaths of most of them. The memory of this experience defined all Turks, including Azerbaijani Turks, as the national enemy, and rendered Armenians acutely sensitive to the perceived threat of a new expulsion from other lands of Armenian settlement, especially Mountainous Karabagh. ${ }^{32}$

Azerbaijanis, for their part, had a much more recent national tradition their very name achieved wide currency only in the 1930s - but their mythology placed the roots of the nation in ancient times, even before the migrations that brought their Turkic language to Azerbaijan. The myths located this national tradition not, therefore, in Azerbaijan's Turkic language or Shi'ite Muslim culture, but in the tradition of politically autonomous entities in the region dating back to ancient times. The awakening of a self-conscious Azerbaijani nation occurred in the aftermath of the 1905 - 6 'Armeno-Tatar War' (Azerbaijanis at that time being called Tatars) and of the fighting between Armenia and Azerbaijan in 1918-20. Armenians thus came to be identified as the enemy of the Azerbaijani nation, 
and Karabagh's secessionist ambitions came to be seen as a mortal threat to the 'statehood' that was at the core of Azerbaijani identity.

Thus from the beginning of the conflict, both sides feared group extinction: the Armenian bugbear was 'genocide', and for Azerbaijanis it was dismemberment of their state. These hostile myths and group fears promoted predatory goals on both sides, with the Armenians calling from the outset for Armenian domination of Karabagh and its transfer to Armenia, while Azerbaijanis soon began calling for revocation of Karabagh's autonomy and its subordination to direct Azerbaijani administration. As a result, a security dilemma quickly emerged in spite of efforts by Communist Party leaders on both sides to dampen down violence: by the end of 1988, some 180,000 Armenians had been 'ethnically cleansed' from Azerbaijan, and 160,000 Azerbaijanis fled from Armenian-inhabited areas. In huge upswellings of mass nationalist sentiments, first Armenia and then Azerbaijan replaced its Communist leadership with nationalists focused on independence from Moscow and on the fight for Karabagh. Karabagh itself mobilised to fight the Turkic enemy, and once the Soviet Union collapsed - allowing the Karabagh Armenians to inherit part of the old Soviet army - the Armenians went over to the offensive, capturing and expelling the inhabitants of Azerbaijani areas in Karabagh, most notably the ancient town of Shusha.

By the time the shooting stopped in May 1994, the Karabagh Armenians, with overt support from Armenia and slightly less overt support from Moscow, had captured nearly 20 per cent of the territory of Azerbaijan, including virtually all of Mountainous Karabagh itself, and expelled the Azerbaijani inhabitants. Azerbaijan was left to cope with the loss of territory and a million refugees on the territory it did control, while it hoped for an oil and gas bonanza that would solve its economic problems and generate the military power to gain revenge on the Armenians. Armenia, for its part, had gained de facto military victory, but it faced a dismal economic picture, with trade shut off on two of its borders (with Azerbaijan and with Turkey), and a population haemorrhaging into the diaspora.

In spite of both sides' desperate need for a peace agreement, however, efforts to reach a deal were repeatedly blocked by the dynamics of the symbolic politics trap. Until 1998, Armenia was led by Levon Ter-Petrosian, hero of the independence struggle and leader of the Armenian National Movement. Ter-Petrosian might have been considered the one man capable of reaching a peace deal, but it became increasingly difficult as corruption, economic stagnation and a badly tainted re-election process sapped his legitimacy.

The most hopeful moment for peace came in September 1997, when TerPetrosian and Azerbaijani president Heydar Aliev accepted an OSCE proposal for a phased approach to peace, involving an Armenian withdrawal from Azerbaijani lands outside Karabagh, in exchange for an opening of economic ties in the region. The Karabagh authorities, however, adamantly 
rejected the idea of withdrawal from any territory before the status of Karabagh was settled, while the powerful Armenian émigré community also weighed in against the plan. In the ensuing backlash, Ter-Petrosian was forced to resign and was replaced by premier and former Karabagh president Robert Kocharian in 1998. This outcome vividly illustrates the symbolic politics trap: even the nationalist hero was unable to 'deliver' his constituents for a desperately needed peace agreement in the face of emotionally charged cries of betrayal.

After Kocharian's elevation, the pivotal place in Armenian politics was taken by the Yerkrapah movement of war veterans, and its political vehicle, the Republican Party led by the ex-defence minister and then prime minister, Vazgen Sarkisian. The road to peace would seem to have been blocked, but even hardliner Sarkisian, once confronted with the reality of Armenia's situation, seems to have swung over to a willingness to contemplate peace. A series of bilateral meetings between Kocharian and Azerbaijani leader Heydar Aliev in 1999 seemed to have been showing promise, but the process was undermined by the assassination of Sarkisian and several other Armenian politicians in a bizarre terrorist attack on a parliamentary session in October. Lacking support on his right flank, Kocharian backed away from a willingness to agree to any realistic compromise.

Aliev was similarly constrained. In spite of his authoritarian control of his country, partly charismatic and partly institutionalised, he, too, had to be sensitive to the virtually unanimous view of the political opposition that any compromise peace was tantamount to betrayal. He responded by conducting all of the Karabagh negotiations himself, fully trusting none of his advisors. But in the atmosphere of extreme nationalism in which Azerbaijani politics takes place, it was not at all certain that even Aliev could ensure the implementation of a peace agreement, should one be reached. Aliev's uncertain health, furthermore, meant that the implementation of any such agreement would be left up to his successor. It also meant that Aliev's attention was increasingly focused on trying to secure the succession for his son Ilham - a succession that might be jeopardised if Ilham were burdened with an unpopular peace agreement with Armenia.

Within Karabagh, a problem exists similar to that in Republika Srpska: the leaders of the rebel enclave have more of an interest in perpetuating the conflict than in solving it. Evidence is murky, but the region seems to be run by a corrupt coterie of politicians and warlords who enrich themselves by facilitating smuggling across the borders with Iran and Armenia. They are disinclined to agree to a settlement, because any deal - even one that leaves them in power and with continuing autonomy - would require that they give up control over Azerbaijani territory outside Karabagh, including the area on the border with Iran. Disinclined to give up any land, they are probably even less inclined to give up their chief source of income.

At the international level, the most important foreign influence on this 
conflict has been Russian military intervention. While Russian support was tilted towards Azerbaijan in 1990-93, that support ended once it became clear in the spring of 1993 that Azerbaijan would insist on the withdrawal of all remaining Russian troops, while Armenia would not. A Kremlinsupported military coup in Azerbaijan, and decisive Armenian military victory, followed. Continued Armenian military superiority was ensured by a continued flow of Russian weapons into Armenia's arsenal, while Russia used its leverage to maintain its military presence in Armenia. Meanwhile, owing to pressure from the Armenian-American community, the United States opened a generous flow of economic aid to Armenia and even to the unrecognised Mountainous Karabagh, while the controversial Section 907 of the Freedom Support Act blocked most American aid to Azerbaijan.

A critical background factor in the management of the Karabagh conflict was the growing push to exploit and market oil and gas from the Caspian basin, especially from Azerbaijan. The most contentious issue was the proposal for an oil pipeline from Baku through Georgia to the Turkish port of Ceyhan, in addition to a parallel pipeline from Baku to the Russian port of Novorossiisk, and a smaller one to the Georgian port of Supsa. US policy promoted the notion of 'multiple pipelines' - meaning, crucially, BakuCeyhan in addition to the others - on the principle that such competition would prevent one actor from gaining either an economic monopoly or a political stranglehold on the transportation of Azerbaijani oil. Azerbaijan hoped that a future oil bonanza shipped through multiple pipelines would shift the political and military balance in its favour, and it tilted towards the US in pursuit of influence that would balance Russia's. Russia, especially given its goal of an exclusive sphere of influence, therefore found itself in the position of wanting to block Baku-Ceyhan precisely in pursuit of a politicaleconomic trump card in the region. To the considerable extent that unresolved ethnic conflicts in Karabagh and in Georgia were considered obstacles to the viability of Baku-Ceyhan, and to the extent that a resolution of the Karabagh conflict would open the door to increased US influence in Azerbaijan, Russia found that a resolution of the Karabagh conflict would not be in its best interests. It therefore refrained from using its considerable leverage to encourage Armenian flexibility in talks with Aliev.

The key diplomatic intervention was the establishment of the OSCE Minsk Group in 1992, and of its system of three (Russian, American and French) co-chairs in late 1994. The temporary breakthrough of September 1997 came in response to a proposal of the co-chairs, but after that period the group was largely sidelined by the process of bilateral Kocharian - Aliev meetings. The two tracks were brought together in a Minsk Group-sponsored negotiating session between the two presidents in Key West in April 2001, but the talks yielded nothing but atmospherics - and the observation by the US co-chair that domestic political constraints on both presidents remain a key obstacle. These official processes have at times been supple- 
mented by an array of unofficial proposals and internationally sponsored peace-building programmes such as a parliamentary exchange programme.

The key failure of the international community has been its inability to bring the diplomatic, political and peace-building tracks together. The negotiating process turned into a way for both governments to pretend interest in a compromise peace while indulging in extremist rhetoric at home (in response to the even more extreme rhetoric of some opposition figures), while Armenia's foreign support was strong enough for it to feel itself able to resist compromise. The peace-building efforts were therefore marginalised. This is the result of a mass-led symbolic politics trap: any moves towards peace threaten the position of incumbent leaders, while leaders' efforts to stay in power block the road to peace. That problem is exacerbated by the most highly motivated outside force, the Armenian diaspora, which promotes the hardline position without suffering the ill effects of continued conflict. Until public opinion on both sides shifts to recognise those ill effects, and the corresponding benefits of a settlement of the conflict, the current deadlock will continue.

\section{Conclusions and future prospects}

There are two main themes in the argument of this chapter. The first is that ethnic civil conflicts such as the ones in Bosnia, Macedonia and Mountainous Karabagh are at the same time regional security issues whose trajectory is critically affected as much by external actors as by internal ones. The second theme is that the behaviour of all parties involved - ethnic groups within states, governments of other states, and others - depends on their construction of their interests. The construction of ethnic group interests, in turn, is heavily influenced by the ethnic mythology of the groups in question, and by the degree of mutual hostility and fear. Many of the groups are caught in a symbolic politics trap from which it is difficult to escape.

This applies also to other conflicts in the region. In Kosovo, for example, the Albanian majority insists so strongly on the goal of complete independence from Serbia that no major Albanian politician dares challenge it - or its implication of continued discrimination against the Serbian minority. The Serbian and Yugoslav governments, for their part, cannot concede the symbolism of Belgrade's sovereignty over the region even though the reality of political authority is irretrievably gone. A similar situation obtains in Chechnya, where legitimate political and guerrilla leaders are locked into the pursuit of independence, while the Russian president Vladimir Putin has built his presidency around a tough 'anti-terrorism' policy that allows him little room even to cede local autonomy to the puppet Chechen administration.

Two conclusions about conflict resolution follow from these thoughts, one commonplace, the other more controversial. The commonplace insight 
is that regional conflict resolution often depends in large part on whether external powers find it in their interest to push for it. Years of sanctions convinced Milosevic's Serbia, for example, to want an end to the war in Bosnia, but as long as Milosevic remained in power, the prospects of reconciliation in Bosnia were blocked by Bosnian Serb hardliners backed by Belgrade. In the Caucasus, Russia's hegemonic goals and the scramble for control of oil and gas routes interacted to give Russia little incentive to push for conflict resolution. Thus conflict resolution was blocked, in the one case at the implementation stage, and in the other case in pre-negotiations. In the Macedonia case, by contrast, all regional and great power actors had incentives to prevent escalation of the conflict, so none encouraged Macedonian hardliners.

The second insight is that ordinary diplomatic, political and even military interventions are not alone enough to achieve effective conflict resolution. Since groups' definition of their interests depends heavily on ethnic myths and group fears, reconciliation and conflict resolution require addressing the mythic roots of group interests, and assuaging the symbolic sources of group fears. This is the way out of the symbolic politics trap, and the tool for doing it is not diplomacy but peace building. To be sure, diplomacy and military coercion have their uses - peace-building efforts need to be backed by diplomatic muscle, and in the case of Bosnia, reconciliation requires coercion by peacekeepers to arrest the war criminals blocking implementation of the Dayton accords. Indeed, in the Bosnian case, destroying the crime nexus organised by war criminals, especially in Serb but also in Croat areas, is the only workable exit strategy for SFOR, and a necessary precondition for peace.

But ultimately, the problems are often attitudinal first, and political or criminal only second. For governments, the key access point to public opinion is the media. That means that foreign governments need to work much harder to push the local media towards more responsible and moderate reporting in all of these conflict areas. Efforts to do so might include the creation and funding of alternative media outlets, and pressure on governments to tolerate and facilitate their reporting. Other opportunities may be less intuitive. If Armenian myths and fears are the key driver of the Karabagh conflict, for example, then the key requirement for conflict resolution may be that Turkey help heal the Armenians' deepest wound by acknowledging and expressing regret for the 1915 Genocide. As with the Bosnia conflict, the key is to get the separatists' outside patron to push for conflict resolution (Serbia in the Bosnia case, Armenia for Karabagh); dealing with the business interests of the separatists must come later.

Supplying the need for peace building requires ever-closer cooperation between diplomats and international institutions such as the OSCE, on the one hand, and conflict-resolution non-governmental organisations (NGOs) on the other. The cultural and ideological clash between these communities 
is by no means the least of the obstacles to effective conflict resolution. Russian and US leaders, in particular, see themselves as hard-nosed realists with little patience for what they see as the soft-headed and impractical peace activists in the NGO community. NGO activists, on the other hand, are fiercely independent and inclined to resist the sort of top-down coordination by officials of any kind that could help them turn their disparate efforts into broadly effective peace-building programmes. While each side needs to adjust and accommodate to the other, the onus is on US and European officials to take the lead in encouraging, funding, coordinating and smoothing the way for the NGOs to do their work in places like Bosnia, Macedonia and Karabagh. Such a transformation does not presently seem to be in the offing. And that means that peace in all three regions will remain tenuous at best.

\section{Notes}

1 Randall L. Schweller, 'Neorealism's Status Quo Bias: What Security Dilemma?', Security Studies, 5:3 (1996), pp. 90-121.

2 A recent prominent convert to this view is Robert Jervis. APSA Presidential Address, APSA Annual Meeting, San Francisco, CA, September 2001.

3 Robert D. Kaplan, Balkan Ghosts: A Journey Through History (New York: Random House, 1993).

4 V. P. Gagnon, 'Ethnic Nationalism and International Conflict: The Case of Serbia', International Security, 19:3 (1994/95), pp. 130-66.

5 Barry R. Posen, 'The Security Dilemma and Ethnic Conflict', Survival, 35:1 (1993), pp. 27-47.

6 Michael E. Brown, 'The Causes and Regional Dimensions of Internal Conflict', in Michael E. Brown (ed.), The International Dimensions of Internal Conflict (Cambridge, MA: Center for Science and International Affairs, 1996), pp. 571602.

7 Misha Glenny, The Fall of Yugoslavia: The Third Balkan War, 3rd rev. edn (London: Penguin, 1996).

8 Examples of works on institutional arrangement for managing ethnic conflict include Donald Horowitz, A Democratic South Africa?: Constitutional Engineering in a Divided Society (Berkeley, CA: University of California Press, 1991); David Lake and Donald Rothchild, 'Containing Fear: The Origins and Management of Ethnic Conflict', International Security, 21:2 (1996), pp. 41-75; Arendt Lijphart, Democracy in Plural Societies: A Comparative Exploration (New Haven, CT: Yale University Press, 1977); and Donald Rothchild, Managing Ethnic Conflict in Africa: Pressures and Incentives for Cooperation (Washington, DC: Brookings Institution, 1997). A prominent recent argument for foreign focus on institutional incentives is Barbara F. Walter, 'The Critical Barrier to Civil War Settlement', International Organization, 51:3 (1997), pp. 335-64.

9 Chaim Kaufmann, 'Possible and Impossible Solutions to Ethnic Wars', International Security, 20: 4 (1996), pp. 136-75; Chaim Kaufmann, 'When All Else Fails', International Security, 23:2 (1998), pp. 120-56.

10 Michael E. Brown, 'Internal Conflict and International Action', in Brown, International Dimensions, pp. 603-28. 
11 James D. Fearon and David D. Laitin, 'Explaining Interethnic Cooperation', American Political Science Review, 90:4 (1996), pp. 715-35.

12 Stuart J. Kaufman, Modern Hatreds: The Symbolic Politics of Ethnic War (Ithaca, NY: Cornell University Press, 2001).

13 Benedict Anderson, Imagined Communities: Reflections on the Origin and Spread of Nationalism (Norfolk: Thetford, 1983); Anthony D. Smith, The Ethnic Origins of Nations (Oxford: Blackwell, 1986).

14 Jack Snyder, From Voting to Violence: Democratization and Nationalist Conflict (New York: W. W. Norton, 2000).

15 Ronald Suny, Looking Toward Ararat: Armenia in Modern History (Bloomington: Indiana University Press, 1993).

16 Kaufman, Modern Hatreds, Ch. 4.

17 For an exception, see Jack Snyder and Robert Jervis, 'Civil War and the Security Dilemma', in Barbara Walter and Jack Snyder (eds), Civil Wars, Insecurity, and Intervention (New York: Columbia University Press, 1999), pp. 15-37.

18 Brian D. Taylor, 'Commentary on Moldova', in Alexei Arbatov (ed.), Managing Conflict in the Former Soviet Union (Cambridge, MA.: MIT Press, 1997), p. 214.

19 John Paul Lederach, Building Peace: Sustainable Reconciliation in Divided Societies (Washington, DC: US Institute of Peace, 1997).

20 Stephen Ryan, Ethnic Conflict and International Relations (Aldershot: Dartmouth, 1990), p. 83.

21 See Kaufman, Modern Hatreds, Ch. 6.

22 Serbs, for example, have been quoted as saying 'Only three things grow [in western Herzegovina], snakes, stones, and Ustashes'. Cited in Glenny, Fall of Yugoslavia, p. 157.

23 Quoted in Kaufman, Modern Hatreds, p. 176.

24 Laura Silber and Allen Little, Yugoslavia: Death of a Nation, rev. edn (New York: Penguin, 1997), p. 209.

25 Jane M. O. Sharp, 'Dayton Report Card', International Security, 22:3 (1997/98), pp. 101-37, esp. 115.

26 International Crisis Group, After Milosevic: A Practical Agenda for Lasting Balkans Peace, International Crisis Group Report, 2 April 2001, p. 201. Available at website, www.intl-crisis-group.org.

27 International Crisis Group, War Criminals in Bosnia's Republika Srpska: Who are the People in Your Neighborhood?, International Crisis Group Report, 2 November 2000. Available at website, www.intl-crisis-group.org.

28 Nenad Dimitrijevic (ed.), Managing Multiethnic Local Communities in the Countries of the Former Yugoslavia (Budapest: Open Society Institute, 2000).

29 H. N. Brailsford, Macedonia: Its Races and their Future (London: Methuen, 1906), pp. 101-3.

30 Kaufman, Modern Hatreds, pp. 193-5.

31 Serbia's interest after its Kosovo defeat was in gaining international agreement for its forces to return to the Presevo Valley, an Albanian-inhabited region inside Serbia bordering on Kosovo and on Macedonia, which also happened to be a base for the Macedonian-Albanian NLA. In the wake of its defeat in the Kosovo conflict, Serbia's best bet was to avert a Macedonian war against Albanians, rather than promote one and provoke another backlash by NATO. The US and the EU wanted stability in the region, and Albania, dependent on the West, was 
not inclined to make waves. Russia may have leaned towards supporting Macedonia's nationalists more than did the Western powers, but newly installed president Vladimir Putin had more pressing problems and did not want to promote trouble. While Ukraine did provide some heavy weapons to Macedonia, its motivations were purely mercenary and the aid did not continue for long.

32 Kaufman, Modern Hatreds, Ch. 3. 